\title{
EU as a Highly Competitive Social Market Economy - Goal, Options, and Reality ${ }^{1}$
}

\author{
Václav Šmejkal, Stanislav Šaroch ${ }^{2}$
}

\begin{abstract}
In paragraph 3 of its Article 3, the Treaty on European Union (TEU) requires the EU to go after the goal of a highly competitive social market economy for the first time. It is noticeable in the aforementioned Treaty clause that although it deals with the EU internal market, its authors burdened it with a mission that is far more sociallyoriented than market-oriented. However, is ,a highly competitive social market economy“ of today a meaningful goal and does the EU in its present form have the project and powers to achieve such an objective? The paper is a combination of economic and legal -political analysis through which the authors try to answer three main questions: What is the contemporary meaning of the term "social market economy" in the both economic and EU-law academic theory? Can the EU within the powers conferred to it positively fulfill such an objective, or can it just approach it by weakening the still prevailing tendency towards liberalization and deregulation brought about by the construction of the EU internal market and by the promotion of its freedoms?
\end{abstract}

Key words: European Union, Lisbon Treaty, social market economy, social policy

JEL Classification: F15, I38

\section{Introduction: EU and the Goal of Social Market Economy}

The Lisbon Treaty that came into force in December 2009 brought numerous changes to the legal basis of the EU, including one novelty with a potentially far-reaching significance. The change at issue is the wording of Article 3 of the Treaty on European Union (TEU) specifying the objectives of the European Union. These objectives, for the first time in the history of European integration, refer to "a highly competitive social market economy, aiming at full employment and social progress". Given that, in parallel, one of the goals proposed originally, i.e. that of free and undistorted competition, was excluded from the integration objectives, many commentators assumed that the Lisbon Treaty would significantly strengthen the social aspects European integration. ${ }^{3}$

\footnotetext{
${ }^{1}$ This paper was created within the project GA CR. Project registration number 14-23623S.

2 ŠKODA AUTO Vysoká Škola o.p.s., Na Karmeli 1457, 293 01, Mladá Boleslav, Vaclav.Smejkal@savs.cz and Stanislav.Saroch@savs.cz.

${ }^{3}$ See for instance: Barnard, C., Deakin, S., Social Policy and labor Market Regulation. In Jones, E., Menon, A., Weaterhill, S. The Oxford Handbook of The European Union, Oxford University Press 2012, p. 551 etc.; Damjanovic, D. The EU Market Rules as Social Market Rules: Why the EU can be a social market economy. In Common market Law Review N. 50/2013; O'Gorman, R.
} 
The view that prevails in the Western European scientific literature is that the European integration has traditionally been far more market-liberal than social-solidarity biased. The founding fathers made the compromise to entrust the supranational bodies of the then EEC with tasks of "negative integration" that could be solved by impartial technocrats on the basis of economic rationality, while the politically sensitive decisions requiring broad social consensus had been left to the Member States. This division of competences, expressed sometimes in shorthand "Keynes at home, Smith abroad,"4 meant that policies, legislation and case law developed at the EU level have been focusing on the "freedoms of movement". This in the course of years has inevitably swung the integration towards deregulation and liberalization of until then nation-specific and preponderantly closed sectors and systems. On the contrary, protection of workers and their social rights, with the exception of safeguards against non-discrimination and of certain harmonization in the field of working conditions facilitating labor migration, have been left in charge of the individual Member States and their historically embedded models of social protection, social dialogue and social services. ${ }^{5}$ The process of globalization, of societal and demographic changes, hand in hand with the progress of deep-going markets opening, however, have gradually plunged the national redistributive social systems, based on local solidarity or even on national corporatism, under the pressure of migrant workers, public tender bidders and service providers representing cheap and dynamic competition. ${ }^{6}$ Any slowdown or even downturn of business cycle then intensified, especially in the most generous welfare states, the summons to the EU to also take care of social rights and solidarity instead of market freedom and competition only.

The EHCR, the EU and the Weakness of Social Rights Protection at the European Level. In German Law Journal Vol. 12 No. 10/2011; Weiss, M. The Potential of the Treaty has to be used to its full extent. In European Labor Law Journal, Vol. 4 No 1/2013.

${ }^{4}$ Micossi, S., Tosato, G.I. Eds. The European Union in the 21ts Century. Brussels: CEPS 2009, p. 36

${ }^{5}$ Expressed strictly, the EU harmonized labor rather than social standards as its limited powers in the area have been related to the need to ensure the functioning of the internal market, including the elimination of differences between Member states that could adversely affect the free movement of workers. Not exhaustive list of EU harmonized standards would thus include: Health and safety at the work place; information and consultation of workers; collective redundancies; working time; maternity leave; posting of workers; part -time and fixed-time contracts; temporary agency work; protection in the event of insolvency etc . Except for the relatively small EU Social Fund and the more recent but tiny European Globalisation Adjustment Fund, the EU has never had tools or means to "re -distribute" in the name of social spending, i.e. no social benefits, no social security ensured and provided directly by the EU. In parallel, fundamental Rights Including social rights such as those enshrined today by the EU Charter have been recognized by the ECJ as part of guiding principles of EU law. It means that they must be observed in EU policies and legislation but do not themselves provide a legal base for the individual or collective claims of EU workers or citizens. See for instance: Pelkmans, J. How social the single market? In CEPS Commentary, 13 April 2010. Brussels: CEPS, 2010. Available at: http//:www.ceps.eu

${ }^{6}$ Trybus, M., Rubini, L. The Treaty of Lisbon and the Future of European Law and Policy. Cheltenham: Edward Elgar Publishing, 2012, p. 383 
The development of European Union towards greater consideration of social aspects gained pace at the time when the then EEC slowly began to open up to Eastern Europe, as it can symbolically be dated from the adoption of (not binding) Community Charter of Fundamental Social Rights of Workers in December 1989. This was followed by amendments to the primary law approved especially in Maastricht and Amsterdam until the beginning of the new millennium when this process culminated in the Article I- 3 of the draft Constitutional Treaty (CT) that called for a highly competitive social market economy which would aim to achieve full employment and social progress. After the failure of CT's ratification (caused by inter alia "social deficit" of the EU, perceived in some countries) this target was copied to Article 3(3) TEU in its Lisbon's currently applicable version.

Among the "social" innovations of the Lisbon Treaty one has to note also the Article 9 TFEU containing the so-called "horizontal social clause", a general obligation of the EU to take into account in all its measures, policies, and decisions "promotion of a high level of employment, the guarantee of adequate social protection, the fight against social exclusion, and a high level of education, training and protection of human health". Moreover, the Lisbon Treaty in Article 6, paragraph 1 has made part of primary EU law the Charter of Fundamental Rights of the European Union, which includes Title IV "Solidarity" containing provisions on workers' right to information and consultation; right of collective bargaining and action; protection in the event of unjustified dismissal or right to social security and social assistance. Although it has always been understood even by supporters of social Europe that by the Lisbon Treaty neither new specific powers accrued to the EU in the social field nor any directly claimable social rights were given to European workers, the belief that the social aspects of the Lisbon Treaty would "open up opportunities for further strategic development of social Europe" was widely shared. ${ }^{7}$

This paper is trying to review those expectations from a distance of more than four years that have passed since the Treaty of Lisbon came into force, in an attempt to find a possible meaning of the concept of social market economy in the current economic and legal situation of the European Union.

\section{"Social Market Economy" as a Concept in Economic Theory}

The answer to the question of what economic theory means (or previously understood) under the concept of social market economy is not clear for several reasons.

The first reason is that the concept of the social market economy itself was born (in the work of Alfred Müller-Armack) as a part or a complement to the German concept of ordoliberalism. As Sojka ${ }^{8}$ points out, this school is usually overlooked in English and American literature. One of the most outstanding representatives of the original ordolib-

\footnotetext{
${ }^{7}$ Špidla, V. Social aspects of the Lisbon Treaty. Speech in the European Parliament, Brussels, 29 April 2009

${ }^{8}$ Sojka, M. Dějiny ekonomických teorií. Praha: Havlíček Brain Team, 2010.
} 
eralism, Walter Eucken, was also the founder of the Freiburg School of Economics and Law, where together with other colleagues he sought to combine theoretical approaches of both economic and legal science in order to apply them on the issues of market economy and economic policy. From the perspective of the history of economic thinking the concept of ordoliberalism, so with its part or a complement - the concept of the social market economy, lies out of the main stream economic thinking and can well be classified among the major directions of institutional economics. Some authors then consider the whole concept of ordoliberalism a predecessor of constitutional economics. Ordoliberalism containing also the concept of the social market economy can be better described as a "theory of economic policy" as Quéré, Coeur, Jacquet and Pisani - Ferry define it. ${ }^{9}$ According to them, the theory of economic policy must use (in addition to knowledge of other sciences) all three currently coexisting and mutually complementary approaches of economics to analysis and evaluation of possibilities of implementation of economic policy. In the first two cases, it is the positive and the normative approach, in the case of the third one, it is the approach called political economics: "In positive economics, the economist takes the point of view of an outside observer and aims at determining the channels through which public decisions affect private behavior" while "in normative economics the economist adopts the posture of an adviser....and examines which set of decisions can best serve explicit public policy purposes". Political economics approach then "instead of considering behavior of political decision makers' as exogenous, it treats it the same way it treats behavior of private agents..... The government is therefore no longer regarded as a Deus ex machina that monitors and steers private economy in the name of general interest but, instead, as a machine directed by politicians, i.e., by rational players whose behavior follows specific objectives and faces specific constraints." ${ }^{10}$ The last - the third part of the definition does not of course fully correspond with the concepts of ordoliberalism and social market economy. On the contrary - in a nutshell, it reflects the progress between the perception of theory of economic policy of the representatives of the Freiburg School and the concept of the social market economy and the current main stream of a comprehensive theory of economic policy. While the Weberian view of politicians or state officials subject to them simply assumes them to altruistically act in the public interest, which so typical for the time period when ordoliberalism was born, political economics abandons this assumption. The concept of the social market economy is - and at the time of its inception was - a distinct part of a comprehensive theory of economic policy rather than a pure economic theory.

The second reason for the ambiguity of the current interpretation of the concept of social market economy in the economic theory is that - as again coincides with a number of authors - in current research works economics as a discipline has become too specialized, too narrowly focused, broken into the sub-disciplines, which usually have a procedure for determining the hypothesis, its verification or falsification on the data followed

\footnotetext{
${ }^{9}$ Bénassy-Quéré, A., Coeuré, B., Jacquet, P. and Pisani-Ferry, J. Economic Policy, Theory and Practice. Oxford: Oxford University Press 2010, pp. 4-9.

${ }^{10}$ Ibid. pp. 4-9.
} 
by some interpretation, but in this form, and with this methodology it may not have the ambition to give answers to practical questions of economic policy not to mention when they are associated with a priori value preferences pronounced and declared and enforced by political leaders, although they are embodied in documents such as TFEU being a long-term political commitment. In his famous article in Foreign Affairs, Alan Blinder ${ }^{11}$ deals very sensitively with issues of optimal determination of value priorities of the society by politicians and their subsequent achievement in a form of "policy design" by educated technocrats.

The third reason for the ambiguity of the meaning of the term social market economy in economic theory (or rather already in the theory of economic policy) is that the founders of the concept themselves endowed it with the principles of solidarity at one, and subsidiarity at the other side. In the context of European integration where the concept of subsidiarity was transferred, it is being used to defend the asymmetric transfer of responsibilities and powers to the supranational level. In this context, Baldwin and Wyplosz even refer to asymmetric integration, or even omitted integration in the area of social policy and taxation. ${ }^{12}$

For the above reasons explaining the ambiguity of the term "social market economy" in economic theory, we chose to define the term in the following way. To return to the original meaning of the term "social market economy," we return to the definition by the members and associates of the Freiburg school. For the definition in the contemporary theory we turn to teleologically oriented parts of economic theory, such as the OCA theory while trying to look for normatively oriented recommendations for economic policy by established experts in the field of theoretical economics. In many cases, we can trace the fact that these authors publish in two, eventually multiple genres: On the one hand, these are very tightly focused research works, fulfilling the usual methodological- scientific claims, and on the other, normatively oriented "policy papers" which cannot be considered pure science.

The original meaning of the term social market economy in the works of the representatives of ordoliberalism can be characterized by the fact that ordoliberalism itself builds on the so-called "politics of order" (Ordnungspolitik), where the role of the state is perceived as irreplaceable for creation of the environment and for guaranteeing the quality of formal institutions (constitution, laws). In the concept of Eucken ${ }^{13}$, functional price system is a basic principle for establishing economic order. Because of the interdependence of social and economic order the existence of price system requires the fulfillment of six basic principles.

1. Dominance of monetary policy guaranteeing price stability.

2. Free markets without entry restrictions.

\footnotetext{
${ }^{11}$ Blinder, A. Is government too political? Foreign Affairs, vol. 76, iss. 6/1997, pp. 115-126.

${ }^{12}$ Baldwin, R. and Wyplosz, Ch. The Economics of European Integration. Berkshire: McGrawHill Education 2012.

${ }^{13}$ Eucken, W. Zásady hospodářského řádu. Praha: Liberální institut 2004.
} 
3. Private property (with a protection of competitive market environment).

4. Freedom of contract (again, subject to the protection of the competitive market environment).

5. Strong responsibility for liabilities (and event. losses) from transactions of market participants gaining benefit from them.

6. Stability of economic policy (fixed rules that reduce the level of uncertainty - here it is again argued by possible damage of competition and strengthening of autonomous tendency to cartelization in the case of a higher degree of uncertainty)

These basic principles then correspond to the requirements on regulatory policy in addressing market failures and corrective (social) policies limiting inequalities arising from the existence of the market system correcting the degree of inequality and strengthening social cohesion. In this conception the control monopolies is the first group of permissible regulatory interventions followed by regulation of income through progressive taxation, regulation and control of externalities and of too high intensity of competition (e.g. in labor markets). Essentially, social policy has to stay next to the functioning price system and market competition and correct the allocation of income in accordance with the principles of solidarity and subsidiarity. To this purpose progressive redistributive taxation can be applied together with social policies associated with various measures in favor of the worse-off layers of the society (child allowances, rent subsidies, social housing, etc.). The intervention should only take place where the problem has arisen (subsidiarity) and only in cases where people are unable to take care of themselves (the so-called legitimate poverty as defined by Murray ${ }^{14}$ ).

In contemporary theory usually addresses the idea of a social market economy represented by its basic instrumental ideals. It is especially the subsequent correction of too high level of inequality and possible suppression of the phenomenon of reproducing social exclusion connected with the results of the market distribution that is being discussed in relation to the challenges of globalization and European economic integration. Baldwin $^{15}$ and Blinder ${ }^{16}$ point to the new challenges in redefining the role of the state (or public sector at any - European, national and regional - level) due to the increasing pressures of globalization transferring competition from the level of "among competitors" level up to the level of "among departments and individuals".

A number of authors of the OCA theory postulate the need for greater symmetry between monetary integration and centralization of fiscal, respectively, social policy (the part of which would include both a European tax and the implicit transfers). Other authors, such as Buti ${ }^{17}$, De Grauwe ${ }^{18}$ or Pisani - Ferry ${ }^{19}$, speak of "Post-crisis inconsistent

\footnotetext{
${ }^{14}$ Murray, Ch. Přiliš mnoho dobra. Praha: Občanský institut 1998.

${ }^{15}$ Baldwin, R. Globalisation as the great unbundling(s): What should governments do? (2008) [online]. [cit.2014-03-09]. Available: http://www.voxeu.org/article/making-globalisation-workskills-families-unions-and-welfare-state.

${ }^{16}$ Blinder, A. ,S., Offshoring: The Next Industrial Revolution? In Foreign Affairs, 85:2/ 2006, pp. 113-128.

${ }^{17}$ Buti, M. A consistent trinity for the Eurozone (2014). A consistent trinity for the Eurozone
} 
trinities" etc., or in other words, of a need for an adjustment of the institutional framework of the EU so that the ideas of social market economy remain fulfilled. Very briefly expressed - in order to sustain the European social model, the EU, or the Eurozone, need: (i) fiscal union, including common implicit transfer; (ii) banking union, including effective mechanism for crisis management and fiscal brakes; (iii) universal mechanism for restructuring sovereign debt which would at the same time eliminate the moral hazard of governments (in the current situation, especially for the south countries); (iv) maintaining the targeted inflation rate and staying off the trap of debt deflation; (v) implementation of structural reforms, especially in the content of education and teaching methods, on labor markets, including more meaningful structure of trade unions.

\section{Lisbon Treaty and Its "Social Market" Potential}

It is not easy to figure out what exactly the drafters of the Treaty had in mind when they adopted the objective of social market economy. It is also far from obvious what interpretation should be given to this provision of the legally binding document with the highest legal force, and to foretell what practical significance it could have for EU legislation and case law.

Historically, the expression "a highly competitive social market economy" appeared for the first time in the third paragraph of Article I-3 of the draft CT. ${ }^{20}$ Although the wording was not fully identical to that of the current Article 3(3) TEU, its segment "based on balanced economic growth and price stability, a highly competitive social market economy aiming at full employment and social progress ..." reads exactly the same in both documents. This text is the result of negotiations originally within the Working Group XI - Social Europe of the Convention (in charge of the CT drafting), as confirmed by its Report from February 4, 2003. ${ }^{21}$ The fact that objectives of the Union made then for the first time reference to "social market economy" was a compromise achieved between those who lobbied for the reference to European social model and those who pushed for maintaining the reference to an open market economy with free competition (as already contained in Article 4(1) of the existing EC Treaty). This reference was therefore adopted to satisfy both sides and to underline the link between the economic and the social, as well as the EU efforts to ensure greater coherence between economic and social policies. $^{22}$ It was not easy to insert this goal into the final draft of CT as its wording from February 6, 2003, still did not mention it, then the next version of May 28, 2003 already

[online]. [cit.2014-03-09]. Available: http://www.voxeu.org/article/consistent-trinity-eurozone.

${ }^{18}$ De Grauwe, P. Design failures in the Eurozone: can they be fixed? In European Economy, Economic Papers No. 491/ 2013.

${ }^{19}$ Pisani-Ferry, J., The euro Crisis and the new Impossible Trinity. In Moneda y Credito 234/2012.

${ }^{20}$ Official Journal of the European Union C $310 \mathrm{Vol} 47$, December 10, 2004. Available at

http://eur-lex.europa.eu/JOHtml.do?uri=OJ:C:2004:310:SOM:en:HTML

${ }^{21}$ Final Report of Working Group XI on Social Europe CONV 516/1/03, Brussels, 4 February 2003. Available at http://www.europarl.europa.eu/meetdocs_all/committees/conv/20030206/cv00516-r1.en03.pdf

${ }^{22}$ See footnote 6, the Final Report CONV 516/1/03, p. 12. 
did, and the whole expression "a highly competitive social market economy" finally appeared for the first time ever in the next draft from June 10, 2003. ${ }^{23}$

According to analysts, this wording reflected a clear compromise in the corridors of power $^{24}$ and strictly speaking, it was even a meta-compromise, as the wording proposed by the Working Group Social Europe (WGSE) had already included a concession made by those who pleaded for more social Europe. Members of WGSE could not agree on proposing any extension of EU competences in the social field, thus described them as "adequate" and merely emphasized the requirement of equivalence between economic and social objectives of the EU. ${ }^{25}$ Therefore, the WGSE Report did not propose a "social Union", but a social market economy, and thus ceded ground to proponents of open market with free competition. In the subsequent compilation of the final draft of the whole CT yet another re-balancing compromise had to be struck, and the social market economy became "highly competitive". Commentators appreciated it as a catch-all expression, good to give simultaneous recognition to both social and economic interests at stake ${ }^{26}$ or as an attempt to balance the EU goals when one goal with right wing focus offsets another goal with rather leftist orientation. ${ }^{27}$ The target itself was commented upon as vaguely defined ${ }^{28}$ and most likely not intended as an appeal to copy the postwar German economic policy. It is most likely that the drafters just borrowed the ideal of a possible compromise between the economic growth and competitiveness on the one hand, and the social-oriented redistributive measures on the other. ${ }^{29}$

${ }^{23}$ Joerges C., Roedl, F. Social Market Economy as Europe's Social Model? EUI Working Papers Law No. 2004/8 Badia Fiesolana, San Domenico 2004, p. 10.

${ }^{24}$ Craig, P. The Lisbon treaty - Law, Politics, And Treaty Reform. Oxford University Press 2013, p. 313.

${ }^{25}$ Description of social competences of the EU as "adequate" was simply an escape from any assessment that might provoke a clash in the Convention. In the course of the CT being drafted, experts assessed the EU social competence as follows: "A large range of socio-political regulations, special legal anchor of social policy in the EC Treaty, as well as the policy of economic and social cohesion, give rise to the belief that the $\mathrm{EC}$ is of considerable importance in relation to establishment of a European social order. These appearances are deceptive, however. Analysis of the relevant provisions of Community law shows that the EC has in the social field only fractional and limited powers. The main part of the social rights and the social policy as such remain a matter for Member States. In contrast to e.g. agriculture or transport, in social matters the Community has no extensive powers to set the detailed structure of the European social order". Quotation from Dauses, A.M. Přiručka hospodářského práva EU (Handbook of EU commercial law). Praha: ASPI 2002, p. 219 (translation from the German original: Handbuch des EUWirtschaftsrechts. Munchen : Verlag CH Beck, 2002).

${ }^{26}$ Costamagna, F. The Internal Market and the Welfare State after the Lisbon Treaty. In Research Paper Observatoire social européen No. 5 April 2011, p. 7 Available at: http://www.ose.be.

${ }^{27}$ Syllová, J., Pítrová, L., Paldusová, H. a kol. Lisabonská smlouva, Komentář. Praha: CH BECK 2010, p. 15.

${ }^{28}$ Buecker, A. A Comprehensive social progress protocol is needed more than ever. In European Labour Law Journal Vol 4 No 1/2013, p. 12.

${ }^{29}$ Blancke, H.-J, Mangiameli, S. Eds. The Treaty on European Union (TEU) A Commentary. 
The transcription of the third paragraph of Article I-3 CT into the paragraph 3 of Article 3 TEU took place in the European Council's documents without any noteworthy discussion, just with a footnote that the wording was taken from the results of the 2004 Intergovernmental Conference which approved the CT draft. However, a fierce debate erupted about its second paragraph that in the draft CT's Article I-3 ranked the "internal market where competition is free and not distorted" among the EU objectives. Under pressure from the then French President, N. Sarkozy, the European Council meeting in Brussels on June 21-22, 2007, decided to drop the reference to free and undistorted competition, stressing nevertheless its importance in a new Protocol 27 "On internal market and competition" added to the Treaty. This symbolic swap can also be read as an expression of resistance by more balanced Europe proponents, not just in France, against too (neo)liberal direction of the European integration. ${ }^{30}$ Reference to free and undistorted competition has been missing from then not only in the Treaty articles on the EU objectives, but did not appear either among horizontally applicable clauses of TFEU. It sparked a controversy about whether the EU was really undergoing "a major reorientation", as N. Sarkozy immediately stressed in his interpretation of the event. ${ }^{31}$

It is really hard to dispute that the inclusion of the objective of social market economy, however vaguely defined, into the legislative text of the highest legal force and into its opening provisions, which the legal doctrine classifies as "core provisions", or even as "Constitutional" and "overreaching directive principles", should have some practical significance and weight. ${ }^{32}$ The rule says, at least since the judgment of the ECJ in the case 6/72 Continental Can (1973), that these target provisions of the Treaty are not "provisions that merely contain general program devoid of legal effect". They must be understood as "indispensable for the achievement of the Community's task", therefore must be followed by policies of EU bodies. ${ }^{33}$ In practice, this means not only that all the institutions forming and implementing EU policies must properly take them into account. ${ }^{34}$ The most important consequence is that if a certain measure of the EU or of Member State acting in the field covered by EU law denies or openly ignores these objectives, it could be declared contrary to EU law by a decision of the ECJ, which in

Berlin: Springer 2013, p. 173; Joerges C, Roedl F. Social Market Economy as Europe's Social Model? EUI Working Papers Law No. 2004/8 Badia Fiesolana, San Domenico 2004, p. 11.

${ }^{30}$ See for instance: A Less 'Anglo-Saxon' EU: Sarkozy Scraps Competition Clause From New Treaty. In Speiegel Online International, June 22, 2007. Available at

$\mathrm{http} / /$ www.spiegel.de/international/europe/a-less-anglo-saxon-eu-sarkozy-scraps-competitionclause-from-new-treaty-a-490136.html

${ }^{31}$ See La concurrence n'est plus un "objectif en soi" de l'UE. In Capital.fr 23/06/2007 Available at: http://www.capital.fr/bourse/actualites/la-concurrence-n-est-plus-un-objectif-en-soi-de-l-ue235729

${ }^{32}$ Blancke, H.-J, Mangiameli, S. Eds. The Treaty on European Union (TEU) A Commentary. Berlin: Springer 2013.

${ }^{33}$ Judgment of the Court of 21 February 1973. - Europemballage Corporation and Continental Can Company Inc. v Commission of the European Communities - Case 6-72 para 23.

${ }^{34}$ Blancke, H.-J, Mangiameli, S. Eds. The Treaty on European Union (TEU) A Commentary. Berlin: Springer 2013. p 167. 
the case of an EU legal act would lead to its annulment. ${ }^{35}$ It is therefore of utmost importance to examine whether the TEU or Treaty on Functioning of European Union (TFEU) give some more specific content to the goal of social market economy and whether they authorize the EU to its fulfillment.

Regarding direct clarification of the term, neither TEU nor TFEU offer any indication as to its content. One can try to construe it using the wording of Article 3(3) TEU, as well as other provisions of the Treaties, especially those that are of general importance for balancing between the economic and the social or directly for building of social Europe. In addition to the term "social market economy", Article 3(3) TEU contains other 17 targets. Of these, a maximum of 4-5 can be classified as market oriented objectives: internal market; balanced economic growth and price stability; scientific and technological progress; and of course the very requirement that the social market economy (which already contains within itself a market component) must be highly competitive. The other objectives (aim at full employment and social progress; combat social exclusion and discrimination; promote social justice and protection etc.) are either explicitly social and solidarity oriented or rather cultural and ecological (safeguard cultural heritage; high level of protection and improvement of the quality of the environment etc.).

Some commentators assess this enumeration of targets as a mess with no clear guidance for political or legislative activity. Analytical report of the British House of Lords quoted on this issue the opinion of Sir David Edward that the objectives of the Treaty "might be said to amount in some respect to little more than a wish list" and that such a "proliferation of objectives, without any very clear indication of which are to take precedence over others, is going to create difficulty". ${ }^{36}$ In order to infer from the wording of Article 3(3) TEU some specific mission, some authors point out that this entire paragraph begins with a short and laconic sentence: "The Union shall establish an internal market". Therefore, all what follows, i.e. all the other objectives listed in the paragraph, should be understood as characteristics of this historically paramount and everlasting goal of European integration. ${ }^{37}$

From this perspective, however, the social market economy looks as somewhat incongruous feature of the internal market. It lacks any explicit command to optimize, similar to more explicit objectives, such as to support economic growth, to work for full employment, to combat social exclusion etc. Comparing to them, the social market economy is not, strictly speaking, an objective at all. If understood in its original West German meaning, it designs rather a major strategic approach towards the economic and social order of a society, not just an amendment to policies that underpin and further

\footnotetext{
${ }^{35}$ Ibid. p 161, also Institute for European Integration research - Working Paper series - EU Policies in the Lisbon Treaty: A Comparative Analysis. Gerda Falkner Eds. WP No 03/2008 Austrian Academy of science, December 2008, p. 61.

${ }^{36}$ House of Lords, European Union Committee, The Treaty of Lisbon: an impact assessment. Vol. I: Report (10th Report of session 2007-08) Published March 13, 2008 HL Paper 62-I, p. 21.

${ }^{37}$ Blancke, H.-J, Mangiameli, S. Eds. The Treaty on European Union (TEU) A Commentary. Berlin: Springer 2013, p. 170.
} 
develop its "internal market". ${ }^{38}$ Downgraded to internal market activities of the EU, it could likely mean the necessity to always respect the balance between the economic and the social, never to scarify one to another. But does this mean that the objective of social market economy amounts to nothing more than to a commandment to look for compromise between economic freedoms and protection of social rights in all activities of the EU and the Member States?

A possible answer can be found, according to opinions of some, in the "horizontal social clause" of Art 9 TFEU and more specifically in the wording of Article 151 TFEU, which opens its Title X "Social policy". It says that lasting high employment, improved living and working conditions, proper social protection, dialogue between management and labor etc. will ensue not only from the functioning of the internal market (which at least - as the Treaty framers believed - will favor the harmonization of social systems). There would also be the need of "regulation or administrative action" as provided for in the Treaties as well as the approximation of provisions laid down by law. Although it is not a sufficiently specific and structured expression of objectives and corresponding measures, some take it for the base from which an EU (social and economic) model can be developed. ${ }^{39}$ Other authors, however, argue against the interpretation that Article 3(3) TEU points towards stronger EU harmonization and investments in the name of social objectives. ${ }^{40}$ They stress the wording of Articles 119-120 TFEU (Title VIII "Economic and monetary policy") which directly refer to the implementation of Article 3 TEU by the EU and Member States. In its four paragraphs laying down principles to be followed, the principle of "an open market economy with free competition" is quoted three times (!) and regarding other guiding principles listed there, they are: stable prices, sound public finances and monetary conditions and a sustainable balance of payments. The logic of social protection and solidarity and the logic of fiscal austerity and free competition do not match each other easily, even if their marriage should take place in one Member State, under the single authority and based on the same tradition. Difficult power sharing between EU and its members and different national models of social security, social dialogue and social services make any draft of EU policy satisfying the logic of both 119 and 151 TFEU Articles a mission almost impossible be it just in theory and even more in practice.

\section{Social Market Economy As a Mere Appeal For Social-Market Balance}

A certain progress in the interpretation of the social market economy objective can after all be accomplished thanks to analysts that claim that this objective is not the basis for positive action, but far more a limiting principle, or even the break to any further devel-

\footnotetext{
${ }^{38}$ Joerges C, Roedl F. Social Market Economy as Europe's Social Model? EUI Working Papers Law No. 2004/8 Badia Fiesolana, San Domenico 2004, p. 19.

${ }^{39}$ Buecker, A. A Comprehensive social progress protocol is needed more than ever. In European Labour Law Journal Vol 4 No 1/2013, p. 17.

${ }^{40}$ Craig, P. The Lisbon treaty - Law, Politics, And Treaty Reform. Oxford University Press 2013, p. 313.
} 
opment of European integration in one-sided direction. Referring to Germany's post-war economic model that provides the only historically fixed content of the social market economy concept, Joerges and Roedl conclude that in its core there is not the priority of the social. Right the opposite is true, as there is a clear restriction of instruments to achieve any social objective at all. ${ }^{41}$ The reason is that the original concept of social market economy contained an ordoliberal basis which was only complemented by social and societal policies, whose aims and instruments were supposed to reply on market mechanism. A social market economy is therefore about market-compatible corrections of an otherwise free market, not about building welfare state or social Union. In contrast, Costamagna, considers the inclusion of the social market economy into TEU in the context of other social clauses and provisions of the Lisbon Treaty and infers that this objective poses a clear limitation to further liberalization and deregulation measures of the internal market. It is about strengthening the social rights against internal market freedoms and so it is a signal not that much for EU legislators but for the ECJ to rebalance social rights and market freedoms in favor of stronger position of the former ones. $^{42} \mathrm{Be}$ it that way or the other one, the social market economy objective thus does not open the door to any flood of new EU legislation designed to achieve this vaguely defined goal. It should rather be seen as a defensive clause, as a possible judicial brake that should prevent the EU from switching to either socialism or neoliberalism. ${ }^{43}$

This assessment of importance of the social market economy objective looks plausible even after a more detailed legal analysis of Treaty provisions. The strengthening of social aspects of the EU was incorporated into the Lisbon Treaty at the symbolic level, not at the practical one because the EU did not receive any substantial powers to build its own social model. First, there is no doubt that neither Article 3(3) TEU nor the horizontal social clause in Article 9 TFEU nor the principles ${ }^{44}$ set out in Title IV Solidarity of the Charter of Fundamental Rights give individuals the rights which they could directly claim before the institutions of the EU or Member States. ${ }^{45}$ Second, it should be emphasized that the objectives of the EU, even being codified in the opening provisions of the Treaty, cannot benefit from the rule ius ad finem dat ius ad media, i.e. in this case the right to the result does not imply the right to the means. The EU can legislate only if

\footnotetext{
${ }^{41}$ Joerges C, Roedl F. Social Market Economy as Europe's Social Model? EUI Working Papers Law No. 2004/8 Badia Fiesolana, San Domenico 2004, p. 20.

${ }^{42}$ Costamagna, F. The Internal Market and the Welfare State after the Lisbon Treaty. In Research Paper Observatoire social européen No. 5 April 2011, p. 8. Available at: http://www.ose.be.

${ }^{43} \mathrm{O}$ 'Gorman R. The EHCR, the EU and the wakness of Social Rights Protection at the European Level. In German Law Journal Vol. 12 No. 10, 2011, p. 1853.

${ }^{44}$ Charter provide in some Titles justiciable rights but but in others only so-called ,principles“ that must be observed by institutions when the issue legislative or executive acts and thus become significant for the Courts only when such acts are interpreted or reviewed (see EXPLANATIONS RELATING TO THE CHARTER OF FUNDAMENTAL RIGHTS (2007/C 303/02) Explanation on article 52. Available at http://eurlex.europa.eu/LexUriServ/LexUriServ.do?uri=OJ:C:2007:303:0017:0035:en:PDF

${ }^{45}$ Blancke, H.-J, Mangiameli, S. Eds. The Treaty on European Union (TEU) A Commentary. Berlin: Springer 2013, p. 161.
} 
the Treaty provides for corresponding competence to act in a particular area. ${ }^{46}$ And the wording of the key "social" article 153 TFEU allows the EU only to "support and complement" the activities of the Member States in several social fields, however, at the same time it excludes any EU legislation affecting fundamental principles of national social security systems and rules out any EU act that would apply to pay, to the right of association, to the right to strike or to the right to impose lock-outs.

It is therefore clear that under the provisions of the Lisbon Treaty, the EU itself is not capable of implementing on its own any ambitious program of social measures or collective social rights of workers. ${ }^{47}$ In this respect, nothing should be expected from the so-called flexibility clause of Article 352 TFEU which allows the Union's competences to be adjusted to the objectives laid down by the Treaty when the latter has not provided the powers of action necessary to attain them, as this "escape clause" cannot be used in cases where the Treaties exclude such harmonization (Art 352(3) TFEU). An interpretation of the social market economy objective not as a green light to development of EU social model, but as a defensive principle which should serve not that much to EU legislators as to ECJ judges to reduce bias for the leftist or for the rightist solutions of arising problems, looks therefore very close to reality.

How could the ECJ assume such a role was suggested by its General Advocate (GA), Cruz Villalón, in his Opinion in the case C-515/08 Santos Palhota in May 2010, i.e. after half a year of the effectiveness of the Lisbon Treaty. Addressing the question concerning the legitimacy of national requirements imposed on an employer from another Member State, which posted to the country at issue his employees within the crossborder provision of services, GA proposed to the Court to take account of the new social provisions of the Lisbon Treaty:

However, since 1 December 2009, when the Treaty of Lisbon entered into force, it has been necessary to take into account a number of provisions of primary social law which affect the framework of the fundamental freedoms. Specifically... Article 9 TFEU lays down a 'cross-cutting' social protection clause obliging the institutions 'to take into account requirements linked to the promotion of a high level of employment, the guarantee of adequate social protection, the fight against social exclusion, and a high level of education, training and protection of human health.' That requirement is laid down following the declaration in Article 3(3) TEU that the construction of the internal market is to be realised by means of policies based on 'a highly competitive social market economy, aiming at full employment and social progress.' 48

\footnotetext{
${ }^{46}$ Joerges C, Roedl F. Social Market Economy as Europe's Social Model? EUI Working Papers Law No. 2004/8 Badia Fiesolana, San Domenico 2004, p. 20; Blanke, H.-J, Magiameli, S. Eds. The Treaty on European Union (TEU) A Commentary. Berlin: Springer 2013, p. 164.

${ }^{47}$ Blanpain, R. The Treaty needs to be amended. In European Labor Law Journal Vol 4 no 1/2013 p. 31, Schoemann, I. The Lisbon treaty: a more social Europea at last? In ETUI Policy Brief, European Social Policy, Issue 1/2010, Brussels 2010, p. 5

${ }^{48}$ See OPINION OF ADVOCATE GENERAL CRUZ VILLALÓN delivered on 5 May 2010 Case C-515/08 and JUDGMENT OF THE COURT (Second Chamber) delievered 7 October 2010
} 
However, the ECJ issued a judgment without a single reference to the objectives of Article 3 paragraph 3 TEU or the social market economy. Indeed, according to the EUR- LEX database, this term had never been used by the ECJ in its judgments until then in the whole post - Lisbon period. ${ }^{49}$ At the same time, the ECJ referred several times ${ }^{50}$ to its older, socially questionable judgments C-438/05 Viking Line ${ }^{51}$ and C341/05 Laval $^{52}$ and commentators concluded that the ECJ does not intend to accept, in consequence of the Lisbon Treaty, any significant changes regarding the relationship between economic freedoms and fundamental social rights. ${ }^{53}$ Maybe the brake of social market economy really works in both directions preventing any bias either for neoliberal or socialist solutions. Or maybe the ECJ does not want to do the work that should be carried out by political decision makers as it is not up to judges to draw far reaching political consequences if Treaty framers could not decide what direction the EU should set for.

\section{Conclusion}

In contemporary economic theory, the idea of a social market economy represented by its basic instrumental ideals is usually addressed. A number of authors of the OCA theory postulate the need for greater symmetry between monetary integration and centraliza-

Case C-515/08. Both available at: http://curia.europa.eu

${ }^{49}$ It was the EU's General Court that so far in one judgment from September 2012 (T-565/ 08, Corsica Ferries) used the argument based on the social market economy principle and upheld the Commission's decision not to prohibit a state aid provided to a state controlled company. It argued that "in a social market economy, a reasonable private investor would not disregard, first, its responsibility towards all the stakeholders in the company and, second, the development of the social, economic and environmental context in which it continues to develop" and "for that purpose, the payment by a private investor of additional redundancy payments is, in principle, capable of constituting a legitimate and appropriate practice." It sounds promising, however, only a convinced optimist would call this isolated case in more than four years (since Lisbon Treaty entry in force) a major shift in EU Courtrs' approach towards assessing the balance between the economic and the social.

${ }^{50}$ See for instance C-271/08 Commission v. Germany 15 July 2010 para 47 . Or the the review of recent ECJ case law in Voogsgeerd, H. The EU Charter of Fundamental rights and its Impact on Labor Law: a Plea for a Prportionality-Test „Light“. In Goettingen Journal of International Law 4/2012 - 1, p. 332-334.

${ }^{51}$ Case C-438/05 International Transport Workers' Federation and Finnish Seamen's Union v Viking Line ABP and OÜ Viking Line Eesti, 11 December 2007. Available at: http://eurlex.europa.eu/LexUriServ/LexUriServ.do?uri=CELEX:62005J0438:EN:HTML

52 Case C-341/05 Laval un Partneri Ltd v Svenska Byggnadsarbetareförbundet and Others 18 December 2007 . Available at http://eurlex.europa.eu/LexUriServ/LexUriServ.do?uri=CELEX:62005J0341:EN:HTML

${ }^{53}$ Grimmel, A. The European Court of Justice growing role in the domain of fundamental rights is not a sign of judicial activism, but political insufficiencies. In EROPP - European Politics and Policy, LSE London, August 16, 2013, p. 8-9, Voogsgeerd, H. The EU Charter of Fundamental rights and its Impact on Labor Law: a Plea for a Prportionality-Test „Light“. In Goettingen Journal of International Law 4/2012 -1, p. 332. 
tion of fiscal, respectively, social policy (the part of which would include both a European tax and the implicit transfers). Other authors, speak of "Post-crisis inconsistent trinities" etc., in other words of the need for an adjustment of the institutional framework of the EU so that the ideas of social market economy remain fulfilled. If we perceive the European integration as a process through which Europe wants to face global competition, we must - in addition to structural reforms - ask the question of what kinds of international and global public goods (according to Baldwin 2008) it should try to create to keep the European welfare state. Besides the redefinition of the role of the public sector in areas such as healthcare and education, different types of transnational institutional rules and regulations might be considered international (European) public goods.

From a legal point of view, the social market economy objective seems to have no other specific mission than to order a balancing test between the economic and the social at any occasion when rights arising from either economic freedoms or social protection come into clash. So far, however, this objective has not brought about any significant change of accents in favor of more social EU as it was expected when the Lisbon Treaty came into force. Social market economy means a compromise between free markets and protected social rights and either itself or under provisions of the Treaty does not imply any push towards "social Union" in the sense of specific EU measures that would harmonize social rights and benefits across the EU. The ECJ is also apparently unwilling to use the social market economy goal as a basis for changes to its long-established case law. If any strategic re-orientation of the EU should take place, a shift in its competencies would inevitably have to be approved among Member States, and the Title X TFEU on Social policy would have to be redrafted.

\section{References}

ALESINA, A. (2006). Europe. Retrieved March 9, 2014, from http://www.nber.org/reporter/summer06/alesina.html

BALDWIN, R. (2005). The royalty of CAP madness. Retrieved March 9, 2014, from http://www.voxeu.org/article/royalty-cap-madness

BALDWIN, R. (2008). Globalisation as the great unbundling(s): What should governments do? Retrieved March 9, 2014, from http://www.voxeu.org/article/makingglobalisation-work-skills-families-unions-and-welfare-state.

BALDWIN, R., WYPLOSZ, Ch. (2012) The Economist of European Integration. Berkshire: McGraw-Hill Education.

BARNARD, C., DEKAIN, S. (2012). Social Policy and labor Market Regulation. In Jones, E., Menon, A., Weaterhill, S. The Oxford Handbook of The European Union, Oxford: Oxford University Press.

BÉNASSY-QUÉRÉ, A., COEURÉ, B., JACQUET, P., PISANI-FERRY, J. (2010) Economic Policy, Theory and Practice. Oxford: Oxford University Press, pp. 4-9.

BLANCKE, H.-J, MANGIAMELI, S. (2013). The Treaty on European Union (TEU) A Commentary. Berlin: Springer. 
BLANPAIN, R.(2013). The Treaty needs to be amended. European Labour Law Journal, $4(1)$.

BLINDER, A. (1997). Is government too political? Foreign Affairs, 76 (6), pp. 115-126.

BLINDER, A. ,S., (2006). “Offshoring: The Next Industrial Revolution?” Foreign Affairs, 85 (2), pp. 113-128.

BLINDER, Alan S., (2008). "Offshoring, Workforce Skills, and the Educational System.” In Virtual Global Economic Symposium.

BLOOM, N., KRETSCHMER, T., VAN REENAN, J. (2006). Work-Life Balance, Management Practices and Productivity. In International Differences in the Business Practices and Productivity of Firms. University of Chicago Press, pp. 15-54.

BORSCH-SUPAN, A. Savings in Germany-Part 1 : Incentives. In Public Policies and Household Savings. University of Chicago Press, pp. 81-104.

BUECKER, A. (2013). A Comprehensive social progress protocol is needed more than ever. European Labour Law Journal, 4 (1).

BUTI, M. (2014). A consistent trinity for the Eurozone. Retrieved March 9, 2014, from http://www.voxeu.org/article/consistent-trinity-eurozone

COSTAMAGNA, F. (2011). The Internal Market and the Welfare State after the Lisbon Treaty. Research Paper Observatoire Social Européen No. 5. Retrieved March 12, 2014, from http://www.ose.be

Council of the European Union. (2007). Brussels European Council, Presidency Conclusions 11177/07 REV 1, Brussels.

CRAIG, P. (2013). The Lisbon Treaty - Law, Politics, And Treaty Reform, Oxford: Oxford University Press.

DAGILYTE, E. (2012). Social Values in The European Union: Are They Becoming More Important After the Lisbon Treaty? In Europe on the Strand, Jean Monnet Centre of Excellence, London: King's College.

DAMJANOVIC, D. (2013). The EU Market Rules as Social Market Rules: Why the EU can be a social market economy. Common Market Law Review, (50).

DE GRAUWE, P. (2013). "Design failures in the Eurozone: can they be fixed?" European Economy, Economic Papers No. 491.

ETUC Joint Declaration ETUC/EUCDW, (2010). "For a social Europe and a social market economy" Brussels. Retrieved March 12, 2014, from http://www.etuc.org/sites/www.etuc.org/files/ETUC-EUCDW_Papier-

Endfassung_final_8_Feb_10_1.pdf

EUCKEN, W. Zásady hospodářského řádu. Praha: Liberální institut 2004.

European Parliament (2008). Committee on Constitutional Affairs. Report on the Treaty of Lisbon. (2007/2286(INI)). 
FALKNER, G. (2008). EU Policies in the Lisbon Treaty: A Comparative Analysis. Working Paper No 03/2008. Austrian Academy of science.

Final report of Working Group XI (2003). Social Europe CONV 516/1/03, Brussels, Retrieved March 12, 2014, from http://www.europarl.europa.eu/meetdocs_all/committees/conv/20030206/cv00516r1.en03.pdf

GRIMMEL, A. (2013). The European Court of Justice growing role in the domain of fundamental rights is not a sign of judicial activism, but political insufficiencies. EROPP - European Politics and Policy, LSE London.

HAY, C., WINCOTT, D. (2012). The Political Economy of European welfare Capitalism. Hampshire: Palgrave Macmillan.

House of Lords, European Union Committee (2008). The Treaty of Lisbon: an impact assessment Vol. I: Report, HL Paper 62-I.

JOERGES, C., ROEDL, F. (2004). Social Market Economy as Europe's Social Model? EUI Working Papers Law No. 2004/8 Badia Fiesolana, San Domenico.

KINDLEBERGER, Ch.,P. French Planning. In Planning in Individual Countries. Massachusetts Institute of Technology, pp. 279-303.

KLAUS, V. (2011). Je evropská unifikace (a záměrné oslabování států) řešením nebo spíše krokem ke stále se zvětšujícímu problému? „Challenging Prospects“, Vídeň, from http://www.klaus.cz/clanky/2760

KLAUS, V. (2013). Evropská ekonomika a její perspektivy. Praha: Kongresové centrum ČNB.

KRABEC, T. (2003). Ordoliberalismus a sociální tržní hospodářství. Politická ekonomie, 6, pp. 881-889.

KRABEC, T. (2004). Německé zkušenosti z hospodářsko-politického poradenství. Politická ekonomie, 6, pp. 677-691.

KRABEC, T. (2006). Teoretická východiska soutěžní politiky. Praha: Národohospodářský ústav Josefa Hlávky.

MICOSSI, S., TOSATO, G.I. Eds. (2009). The European Union in the 21ts Century, Brussels: CEPS.

MOUSSIS, N. (2011). Access to European Union, Law Economics Policies 20th Ed. Retrieved March 12, 2014, from http://www.europedia.moussis.eu/books/Book_2/

MÜLLER-ARMACK, A. (1974). Genealogie der Sozialen Marktwirtschaft. Switzerland: Haupt.

MURRAY, Ch. Př́liš mnoho dobra. Praha: Občanský institut 1998.

Official Journal of the European Union, 47. (2004). Retrieved March 12, 2014, from http://eur-lex.europa.eu/JOHtml.do?uri=OJ:C:2004:310:SOM:en:HTML 
O'GORMAN, R.(2011). The EHCR, the EU and the Weakness of Social Rights Protection at the European Level. German Law Journal, 12 (10).

PARIS, P., WYPLOSZ, Ch. (2014). PADRE: Politically Acceptable Debt Restructuring in the Eurozone, In Geneva Special Report on the World Economy 3, ICMB and CEPR.

PELKMANS, J. (2010). How social the single market? CEPS Commentary, Brussels: CEPS. Retrieved March 12, 2014, from http//:www.ceps.eu

PISANI-FERRY, J. (2012). "The euro Crisis and the new Impossible Trinity." In Moneda y Credito 234.

ROTH, F. (2009). The Effect of the Financial Crisis on Systemic Trust. Intereconomics, July/August 2009, pp. 203-208.

SCHARPF, F. W. (2010). The Socio-Economic Assymetries of European Integration or Why the EU cannot be a „Social Market Economy”. In Swedish Institute for European European Policy Studies, European Policy Analysis, (10).

SCHOEMANN, I. (2010). The Lisbon Treaty: a more social Europe at last? ETUI Policy Brief, European Social Policy, (1), Brussel.

SOJKA, M. (2010). Dějiny ekonomických teorií. Praha: Havlíček Brain Team

SYllovÁ, J., PÍTROVÁ, L., PALDUSOVÁ, H. a kol. (2010). Lisabonská smlouva, Komentár̆, Praha: CH BECK.

ŠPIDLA, V. (2009). Social aspects of the Lisbon Treaty. Speech in the European Parliament, Brussels.

WEISS, M. (2013). The Potential of the Treaty has to be used to its full extent. European Labour Law Journal, 4 (1). 